\title{
Thyroid hormone actions on cartilage and bone: interactions with other hormones at the epiphyseal plate and effects on linear growth
}

\author{
G R Williams, H Robson ${ }^{1}$ and S M Shalet ${ }^{2}$ \\ Molecular Endocrinology Group, Department of Medicine, Imperial College School of Medicine, Hammersmith Hospital, London W12 0NN and Departments \\ of ${ }^{1}$ Clinical Research and ${ }^{2}$ Endocrinology, Christie Hospital NHS Trust, Manchester M20 4BX, UK \\ (Requests for offprints should be addressed to G R Williams, Molecular Endocrinology Group, Clinical Sciences Centre, Imperial College School of Medicine, \\ Hammersmith Hospital, Du Cane Road, London W12 0NN, UK)
}

\section{Introduction}

Normal linear growth is determined by variable contributions from genetic, nutritional and endocrine factors and continues until bone maturation and epiphyseal closure in early adulthood. The major systemic hormones that influence growth during childhood include thyroid hormone $\left(\mathrm{T}_{3}\right)$, growth hormone $(\mathrm{GH})$, insulin-like growth factors (IGF) and glucocorticoids, whereas an increasing contribution from sex steroids develops during adolescence (Underwood \& Van Wyk 1992, Weiss \& Refetoff 1996). Recently, two signalling proteins, Indian hedgehog (Ihh) and parathyroid hormone-related peptide (PTHrP), have also been found to be crucial for the co-ordinated regulation of the pace of growth plate chondrocyte differentiation (Lanske et al. 1996, Vortkamp et al. 1996, Wallis 1996). These molecules form an integrated negative feedback loop that regulates the rate of endochondral ossification. However, it is not known how systemic hormones and other local factors that act on the growth plate may regulate expression of Ihh and PTHrP or influence activity of the feedback loop to alter the rate of chondrocyte differentiation during growth.

In this review, we focus on the actions of $T_{3}$ and its interactions with other hormone signalling pathways in the control of growth. The field highlights a poorly studied area that has important applications to understanding skeletal development and the regulation of linear growth. There are large gaps in our knowledge concerning the actions of $\mathrm{T}_{3}$ in bone and cartilage, and fundamental questions have yet to be answered. For example, a current point of controversy is whether the major skeletal effects of $\mathrm{T}_{3}$ result from its direct effects on the skeleton or via interactions with $\mathrm{GH}$ and IGF-1. Recent evidence documenting the expression of $\mathrm{T}_{3}$ receptors in osteoblasts and chondrocytes indicates that direct $\mathrm{T}_{3}$ effects on the skeleton are likely to be important. Despite this, the target genes that are directly responsive to $\mathrm{T}_{3}$ in bone cells have not been identified. Furthermore, the precise localisation of $\mathrm{T}_{3}$-responsive cells within the growth plate and skeleton and the ontogeny of $T_{3}$ receptors in developing cartilage and bone are unknown. Thus it is not clear whether $\mathrm{T}_{3}$ acts directly and independently on both osteoblasts and osteoclasts, in addition to chondrocytes, or whether the effects of thyroid hormones on bone turnover and growth are mediated primarily by one cell lineage and subsequently by other secondary events.

The aim of this review is to summarise the effects of $T_{3}$ on bone and growth plate cartilage and to discuss the interactions between $\mathrm{T}_{3}$ and other hormones and their possible relationship to the fundamentally important Ihh/ PTHrP feedback loop. The roles of other important growth factors and cytokines are beyond the scope of this review. In a discussion of this type, it is important to be aware that much of our knowledge is derived from studies using a variety of animal species, including rodents, cattle, pigs, rabbits and birds, in addition to humans. Thus data can be conflicting, as there are basic differences between species in the growth plate ossification process and in vitro models may not reflect the intact organism. For example, rodent growth plates fuse in late adulthood, whereas this occurs towards the end of adolescence in man. In birds, the system may differ further, as the avian growth plate is more fibrous than its mammalian counterpart. Despite these reservations, there are fundamental similarites in endochondral ossification across species that do allow cautious but valid interpretation of the available data.

\section{Clinical and physiological effects of thyroid hormones on the skeleton}

\section{Effects of thyroid hormones on growth}

$\mathrm{T}_{3}$ is a primary determinant of normal postnatal somatic growth and skeletal development, and an important regulator of bone and mineral metabolism in the adult (Allain \& McGregor 1993, Compston 1993). Before puberty, thyroid hormone may be the major prerequisite for normal maturation of bone (Underwood \& Van Wyk 1992). In contrast, it is not clear if $T_{3}$ is important 
for intrauterine fetal growth, as infants with congenital thyroid aplasia are of normal size at birth and have normal central nervous system development. This may reflect a compensatory contribution from maternal thyroid hormones that cross the placenta in low concentrations, as continued maturation in the neonatal period can only be maintained by early thyroxine $\left(\mathrm{T}_{4}\right)$ replacement.

Untreated childhood hypothyroidism, however, results in profound growth retardation and delayed skeletal maturation. Linear growth is almost completely halted, but can be resumed quickly by replacement of thyroid hormones to produce a rapid catch-up period of growth (Fisher \& Plok 1995, Boersma \& Wit 1997). In contrast, whereas thyrotoxicosis in children is associated with increased bone turnover and accelerated growth rates, the advanced skeletal maturation that also occurs may lead to short stature (Underwood \& Van Wyk 1992, Allain \& McGregor 1993, Weiss \& Refetoff 1996). In adulthood, thyrotoxicosis increases bone turnover (Franklyn et al. 1994) and accelerates bone loss even in the presence of adequate oestrogens (Mosekilde et al. 1990) whereas, in hypothyroidism, excessive $\mathrm{T}_{4}$ replacement has been linked with osteoporosis (Diamond et al. 1991, Schneider et al. 1994), particularly in previously thyrotoxic patients rendered hypothyroid by iodine-131 treatment (Duncan et al. 1994, Franklyn et al. 1994).

\section{Resistance to thyroid hormone}

The syndrome of resistance to thyroid hormone (RTH) (Refetoff et al. 1967) offers further confirmation of the importance of $\mathrm{T}_{3}$ for growth and skeletal development. $\mathrm{RTH}$ is an autosomal dominant condition caused by point mutations of the thyroid hormone receptor $\left(T_{3} R\right) \beta$ gene $\left(\mathrm{T}_{3} \mathrm{R} \alpha\right.$ is normal in all cases) that generate receptors which display impaired responses to $\mathrm{T}_{3}$ and antagonise the actions of wild-type $T_{3} R \alpha$ and $\beta$ proteins (Refetoff $e t$ al. 1993). The condition is characterised by a heterogeneous phenotype that is manifest by variable degrees of tissue hypothyroidism in the presence of increased circulating concentrations of free $T_{4}$, free $T_{3}$ and thyroid-stimulating hormone. The index family contained patients with stippled epiphyses similar to those documented in profoundly hypothyroid children during the 1930s. A recent analysis of RTH families indicated that short stature occurs in up to $16 \%$ of affected children, with delayed bone age in 47\% (Weiss \& Refetoff 1996). These observations highlight the variable phenotype of RTH as, in $84 \%$ and $53 \%$ of cases, growth and bone age respectively, were apparently normal.

The reasons for such variability are not completely understood, but recent genetic evidence now indicates fundamental roles for both $\mathrm{T}_{3} \mathrm{R} \alpha$ and $\beta$ during growth and skeletal development. In $\mathrm{T}_{3} \mathrm{R} \alpha$ knockout mice, there is growth arrest and delayed bone maturation, with disorganisation of epiphyseal growth plate chondrocytes, fewer hypertrophic cells and disrupted endochondral bone formation (Fraichard et al. 1997). $T_{3} \mathrm{R} \alpha$ null mice have markedly reduced thyroid hormone production rates and severe biochemical hypothyroidism. Remarkably, the growth arrest and delayed bone maturation were rescued after $\mathrm{T}_{3}$ replacement, $1 \mu \mathrm{g} /$ day for 1 week (Fraichard et al. 1997). In $T_{3} R \quad \beta$ null mice, in contrast, there is disruption of the pituitary-thyroid feedback axis and profound hearing loss, but little effect on skeletal development and growth (Forrest et al. 1996a,b). The data from knockout studies suggest that $T_{3} R \alpha$ has the critical role in thyroid hormone production after weaning, whereas $\mathrm{T}_{3} \mathrm{R} \beta$ exerts a negative regulatory role on hormone production and release (Fraichard et al. 1997, Forrest et al. 1996a,b). Taken together, these findings make it clear that either $\mathrm{T}_{3} \mathrm{R} \alpha$ or $\mathrm{T}_{3} \mathrm{R} \beta$ can mediate the actions of $\mathrm{T}_{3}$ in the epiphysis and skeleton, but the profound growth disruption seen in $\mathrm{T}_{3} \mathrm{R} \alpha$ null mice results from biochemical hypothyroidism. The data emerging from rodents may, in part, explain the phenotypic variation seen in human RTH. Thus the heterogeneity of growth and bone age delay in RTH may reflect the diversity of mutant $T_{3} R \beta$ proteins found in this condition and their abilities to cause variable degrees of 'target tissue hypothyroidism'.

\section{Direct actions of thyroid hormones on the skeleton}

\section{Thyroid hormone actions in bone}

Only a few studies have investigated $\mathrm{T}_{3}$ actions in bone. High-affinity $T_{3}$ binding sites were identified more than 10 years ago in rat osteoblast lineage cells (Rizzoli et al. 1986) and $\mathrm{T}_{3}$ stimulation of osteoclastic bone resorption was first demonstrated more than 20 years ago in rat cells (Mundy et al. 1976). Since then, further studies have suggested that rat, mouse and human osteoblasts are primary $\mathrm{T}_{3}$ target cells and that osteoclast responses may be secondary, or coupled, to these primary $\mathrm{T}_{3}$ actions (Rizzoli et al. 1986, Sato et al. 1987, Kasono et al. 1988, Krieger et al. 1988, LeBron et al. 1989, Egrise et al. 1990, Allain et al. 1992, Allain \& McGregor 1993, Britto et al. 1994, Klaushofer et al. 1995). Furthermore, expression of $\mathrm{T}_{3} \mathrm{Rs}$ in human osteoblasts and osteoclasts at sites of active bone remodelling has been demonstrated recently by immunohistochemistry (Abu et al. 1997). Thus both osteoblast and osteoclast activities are affected by abnormalities in thyroid status leading to a net imbalance in bone turnover.

We have shown that rat osteoblastic cells express functional $T_{3} R$ proteins in patterns that vary in cells that express phenotypes of differing osteoblast maturity (Williams et al. 1994, Bland et al. 1997). In addition, 9-cis retinoic acid receptors (RXR), which bind to target gene promoters as high-affinity heterodimers with $\mathrm{T}_{3} \mathrm{R}$ (Glass 1994) and help to mediate the actions of $T_{3}$, are co-expressed in rat osteoblastic cells (Bland et al. 1997). 
The related receptors for $1,25(\mathrm{OH})_{2}$-vitamin $\mathrm{D}_{3}$ (VDR) and all-trans retinoic acid (RAR) are additional alternative heterodimer partners for RXR, $\mathrm{T}_{3} \mathrm{R}$ and each other (Rosen et al. 1993, Glass 1994, Schrader et al. 1994) and are also co-expressed in rat osteoblastic cells (Williams et al. 1995, Bland et al. 1997). All these observations support the notion that bone is primarily responsive to $T_{3}$, but that responsiveness is complex and may vary with development and vitamin $\mathrm{D}$ or retinoid status. In spite of this, no clearly documented transcriptionally activated $T_{3}$ target genes have yet been defined in bone cells, although interleukins-6 and -8 (Siddiqi et al. 1996) and IGF binding proteins (IGFBPs)-2 (Schmid et al. 1992) and -4 (Glantschnig et al. 1996) have been implicated in preliminary studies in human, rat and murine species respectively. Findings of a recent study also suggest that IGF-I may be regulated directly by $\mathrm{T}_{3}$ in rat vertebral, but not femoral, osteoblasts (Van Auken et al. 1997).

\section{The epiphyseal growth plate}

In the normal epiphyseal plate, chondrocytes are organised into layers (Fig. 1). At the distal epiphyseal end, chondroblast progenitor cells occur singly and in small clusters to form the reserve cell zone. Progressing towards the metaphysis, and adjacent to the reserve zone, small flat proliferating cells form discrete columns and constitute the proliferative zone. The proliferative cells then lose their ability to divide and undergo a process of differentiation to produce enlarging hypertrophic chondrocytes, which are present within the hypertrophic zone. These hypertrophic cells, situated in the lower region of provisional cartilage calcification, secrete matrix that undergoes mineralisation and is then partially resorbed by chondroclasts or osteoclasts. The largest, most distal hypertrophic chondrocytes undergo apoptosis to leave a cartilaginous framework. The remaining mineralised matrix forms a scaffold for apposition of metaphyseal trabecular bone by invading osteoblasts at the resorption front, and constitutes the primary spongiosum. Invading osteoblasts are derived from bone-marrow stromal cells which enter the primary spongiosum via capillaries that advance from the adjacent marrow cavity.

\section{Thyroid hormone effects on growth plate architecture}

Lewinson et al. (1989) studied the effects of hypothyroidism and interactions between $\mathrm{T}_{3}$ and $\mathrm{GH}$ on rat tibial growth plate morphology. In hypothyroid rats, the width of the epiphyseal plate is reduced as a consequence of the presence of fewer proliferative cells and a reduction in size of hypertrophic cells compared with controls. In addition, mineralisation of the cartilage-marrow interface and absent resorptive activity in this region result in there being no new metaphyseal bone formation and markedly reduced subchondral primary spongiosum metaphyseal trabecular bone in hypothyroid animals. Few, if any, chondroclasts or bone marrow stromal cells are seen. Treatment of hypothyroid rats with $\mathrm{T}_{4}$ reverses these changes. In contrast, treatment of hypothyroid rats with $\mathrm{GH}$ does not result in recovery of the disrupted growth plate architecture unless co-treatment with $\mathrm{T}_{4}$ is instigated. In this case, $\mathrm{GH}$ augments the positive response to $\mathrm{T}_{4}$. Similar effects are also seen in articular cartilage, although GH does not enhance the actions of $\mathrm{T}_{4}$. The important findings from this study (Lewinson et al. 1989) confirm the direct actions of thyroid hormone on the growth plate and exclude the possibility that thyroid responses are mediated via increased GH secretion.

In a follow-up study, the responses of rat mandibular condyle cartilage to hypothyroidism, $\mathrm{T}_{4}$ replacement and GH were documented (Lewinson et al. 1994). The condylar bone responds differently to hypothyroidism and undergoes hyperostosis (osteopetrosis) of the subchondral region, suggesting that the endochondral osteogenic response to thyroid hormone varies according to anatomical site and may be dependent on the particular cells that respond to $\mathrm{T}_{3}$ in each location. In condylar cartilage, unlike in the tibial growth plate, remodelling is not completely blocked and some cartilage scaffold persists, as the cartilage-marrow interface is not mineralised (Lewinson et al. 1994). Despite differences in responses of the two sites to hypothyroidism, their response to replacement with $\mathrm{T}_{4}$ or $\mathrm{GH}$ or both hormones remains similar and requires thyroid hormone to be fully realised. At both sites there is diminished cellularity of the zones containing immature cells in hypothyroidism; these cells are chondrocyte progenitor cells and chondroblasts within the condyle, or reserve and proliferative chondrocytes in the growth plate (Lewinson et al. 1989, 1994). This key observation is likely to be the basis for the fewer hypertrophic cells and reduced differentiation capacity of proliferative cells that is seen in $\mathrm{T}_{3}$ deficiency (Carrascosa et al. 1992, Ballock \& Reddi 1994, Quarto et al. 1992). Both processes would result in the reduced linear growth that occurs in juvenile hypothyroidism.

Further considerations suggest that other mechanisms may also contribute to the actions of $\mathrm{T}_{3}$ at the epiphyseal plate. Terminal differentiation of proliferating chondrocytes into hypertrophic cells is the primary event that characterises endochondral ossification and linear growth. There is a several-fold increase in hypertrophic cell volume that correlates with both the rate of long bone growth and the associated mineralisation of cartilaginous matrix. This mineralised scaffold is the site for new bone formation by osteoblasts, which arrive from the adjacent marrow with invading blood vessels. As the epiphyseal plate is sealed by a mineralised bone marrow-growth plate interface in hypothyroid animals (Lewinson et al. 1989), it is possible that an important action of $\mathrm{T}_{3}$ is to promote or maintain vascular invasion and osteoblast migration to facilitate new bone formation. 


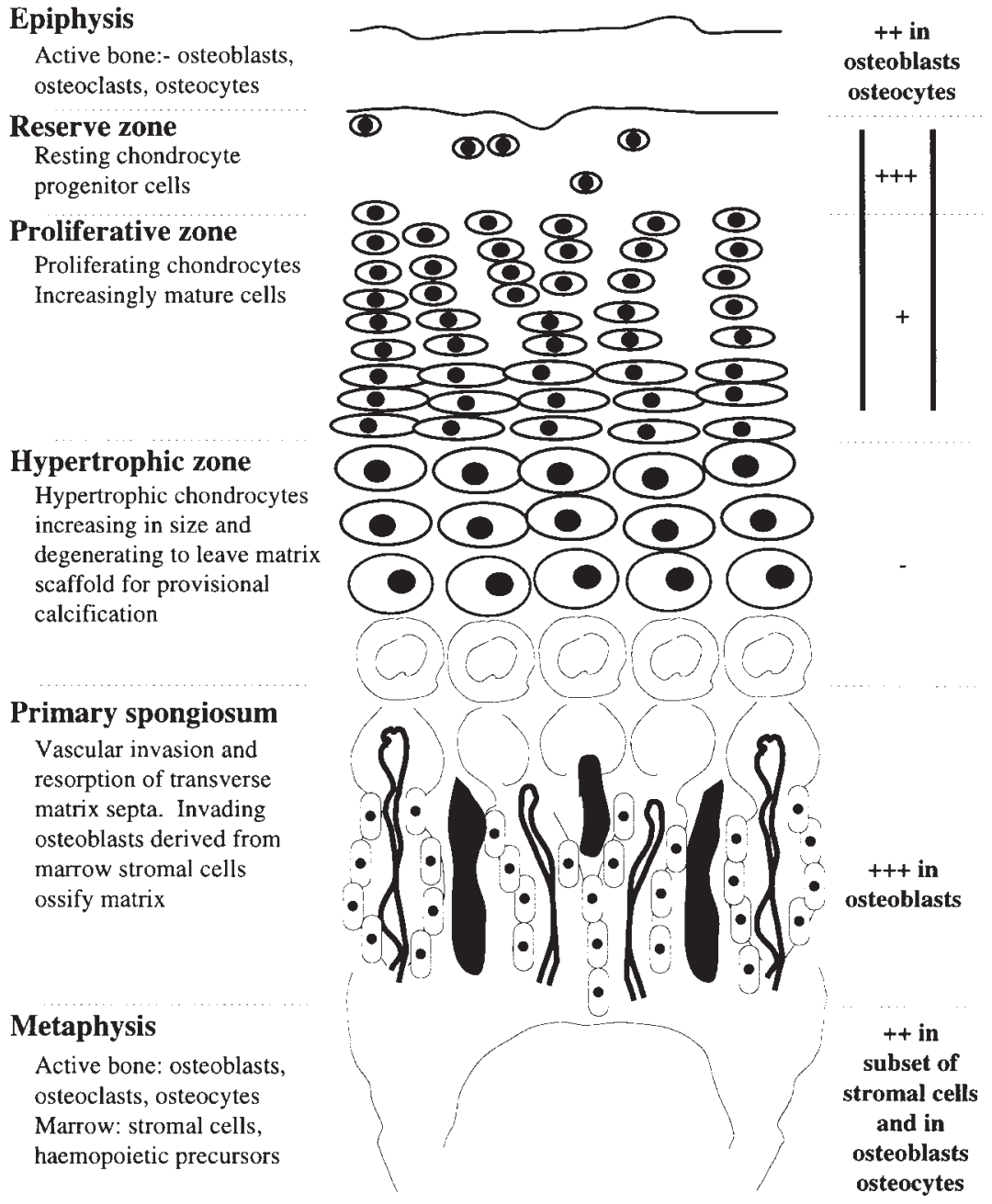

Figure 1 Diagrammatic representation of the layered structure of an epiphyseal growth plate. The epiphysis is situated at the top of the figure and the metaphysis, containing the bone marrow cavity, is located below the cartilaginous growth plate. The sites of expression of thyroid hormone receptor $\left(\mathrm{T}_{3} \mathrm{R}\right)$ isoforms $\alpha 1$ and $\beta 1$ are shown on the right-hand side of the figure: regions of +++ strong, ++ intermediate, + weak, and absent immunostaining for both $T_{3} R$ isoforms are shown. Vertical lines show the limits of staining for $T_{3} R$ within the reserve and proliferative zones. The location of $T_{3} R$ expression in this diagram summarises the findings from our own preliminary studies (Robson et al. 1997), which are shown in Fig. 2.

Thyroid hormone actions on chondrocytes in vitro

Cultured human fetal epiphyseal chondrocytes possess specific nuclear binding sites for $\mathrm{T}_{3}$, with appropriate binding affinities in the nanomolar range (Carrascosa et al. 1992). These cells respond to $\mathrm{T}_{3}$ in vitro, with increased alkaline phosphatase activity after 9 days of treatment. Similarly, treatment of rat epiphyseal chondrocytes with $\mathrm{T}_{3}$ for $96 \mathrm{~h}$ increased alkaline phosphatase activity and IGF-I receptor mRNA expression, in addition to decreasing cell proliferation (Ohlsson et al. 1992). In that study, IGF-I inhibited the alkaline phosphatase response to $T_{3}$. These data suggest the presence of functional nuclear receptors for $\mathrm{T}_{3}$ in chondrocytes, but it is unclear whether the documented effects of $\mathrm{T}_{3}$ are primary $\mathrm{T}_{3} \mathrm{R}$-mediated responses, as the times chosen in both studies were beyond those optimally required to demonstrate transcriptional activation of target genes by $\mathrm{T}_{3}$. 
What is clear, however, is that thyroid hormones are absolutely required for normal chondrocyte differentiation. Indeed, rat cartilage responses to $\mathrm{GH}$ in vivo require thyroid hormones (Lewinson et al. 1989, 1994). In vitro, in studies of three-dimensional aggregates of rat growth plate resting zone chondrocytes, $\mathrm{T}_{4}$ stimulated their differentiation and the columnar organisation of hypertrophic chondrocytes (Ballock \& Reddi 1994). Furthermore, other studies of primary cultured cartilage cells in rat, chicken and porcine species have shown that thyroid hormones induce expression of a hypertrophic phenotype (Burch \& Lebovitz 1982a,b, Burch \& McCarty 1984, Burch \& Van Wyk 1987, Bohme et al. 1992, 1995, Quarto et al. 1992, Ballock \& Reddi 1994), although the mechanisms by which this is achieved and the particular cells that respond to $\mathrm{T}_{3}$ have not been characterised. More recently, these findings were extended by studies of $\mathrm{T}_{3}$-induced hypertrophy of bovine fetal growth plate chondrocytes in subsets of primary cultured cells derived from maturationally distinct prehypertrophic proliferative cells (Alini et al. 1996). These studies revealed that the most immature cells were directly responsive to $T_{3}$ and that $T_{3}$ could support matrix assembly, hypertrophic differentiation (alkaline phosphatase activity and collagen type $\mathrm{X}$ expression) and matrix calcification in serum-free cultures. Again, the molecular mechanisms responsible for these responses were not investigated, as cells were studied after 5-20 days of treatment. Thus it is unknown which genes are direct targets for $\mathrm{T}_{3}$ during the initiation of hypertrophic chondrocyte differentiation.

\section{Localisation of $T_{3} R$ in rat tibial growth plate cartilage}

In a preliminary study (Robson et al. 1997), we determined the expression of the $T_{3} R \alpha 1$ and $\beta 1$ proteins in the rat growth plate by means of immunohistochemistry (Fig. 2 ). In the reserve zone, all chondrocyte progenitor cells exhibited specific nuclear staining for $T_{3} R \quad \alpha 1$ and $\beta 1$, whereas most proliferative zone chondrocytes stained weakly for both $T_{3} R s$. In contrast, chondrocytes throughout the hypertrophic zone to the region of provisional cartilage calcification did not express either $T_{3} R$ isoform. In the metaphyseal primary spongiosum, the nuclei of invading osteoblasts stained strongly positive for both $\mathrm{T}_{3} \mathrm{R}$ variants. Similarly, all osteoblasts and osteocytes in adjacent, highly active, metaphyseal and epiphyseal bone also stained strongly for $T_{3} R \alpha 1$ and $\beta 1$, whereas osteoclasts were negative. These data suggest that the primary target cells for $T_{3}$ within the growth plate are progenitor chondroblasts, immature proliferating chondrocytes and primary spongiosum osteoblasts, together with osteoblasts and osteocytes at adjacent sites of active bone turnover. Thus the localisation of $T_{3} R$ expression in this region correlates well with the known effects of $\mathrm{T}_{3}$ at the epiphyseal plate and enables us to consider how thyroid hormone actions may integrate with other signalling pathways that act on the epiphyseal plate to stimulate linear growth.

\section{Interactions between thyroid and other hormones and their effects on the skeleton}

Interactions between $T_{3}$ and $\mathrm{GH}$

Thyroid hormone is permissive for skeletal growth in that it is required for the expression of many of the skeletal actions of GH (Lewinson et al. 1989, Nilsson et al. 1994). Thus in hypothyroid children there is blunting of the $\mathrm{GH}$ response to provocative stimuli; this probably results from indirect effects of $\mathrm{T}_{3}$ on pituitary $\mathrm{GH}$ secretion, rather than from direct $\mathrm{T}_{3}$ actions at the hypothalamus (Underwood \& Van Wyk 1992, Weiss \& Refetoff 1996). The exact contribution of the change in GH status to the growth disorder seen in hypothyroidism is unclear however. GH does exert direct effects on the growth plate, as shown in several species (Loveridge \& Farquharson 1993, Ohlsson et al. 1993, Nilsson et al. 1994, Spagnoli \& Rosenfeld 1996), and expression of GH receptors has been clearly documented in human and rat epiphyseal plate chondrocytes (Werther et al. 1993). GH increases the width of the growth plate proliferative and hypertrophic zones per se in rats, and also stimulates the commitment of resting layer chondrocytes to a proliferative phenotype (Hunziker et al. 1994), although this also requires the presence of other pituitary hormones (Gevers et al. 1996). Expression of the GH receptor in rat epiphyseal growth plate chondrocytes is likely to be developmentally regulated, with expression in the hypertrophic zone being apparent from birth, and expression in the resting and proliferative zones occurring later when the GHdependent growth period commences (Ohlsson et al. 1993, Werther et al. 1993).

\section{Interactions between $T_{3}$ and IGF-I}

In addition, thyroid hormones influence the IGF-I signalling pathway. In the rat, $\mathrm{T}_{3}$ increases hepatic expression of IGF-I mRNA (Wolf et al. 1989) and enhances the direct effects of IGF-I on cartilage (Ohlsson et al. 1992, Lewinson et al. 1994). Thus hypothyroid cartilage may be refractory to the induction of IGF-I synthesis by GH; in fact, IGF-I immunostaining within condylar cartilage is reduced in hypothyroid rats and requires thyroid hormone for its restoration (Lewinson et al. 1994). In humans with hypothyroidism, there are reductions in GH-binding protein, IGF-I, IGF-II, IGFBP-3 and IGF bioactivity; these changes are reversed after thyroid hormone replacement (Miell et al. 1993). Furthermore, in studies of cultured rat and mouse osteoblastic cells, it has been suggested that IGFBPs-2 (Schmid et al. 1992) and -4 


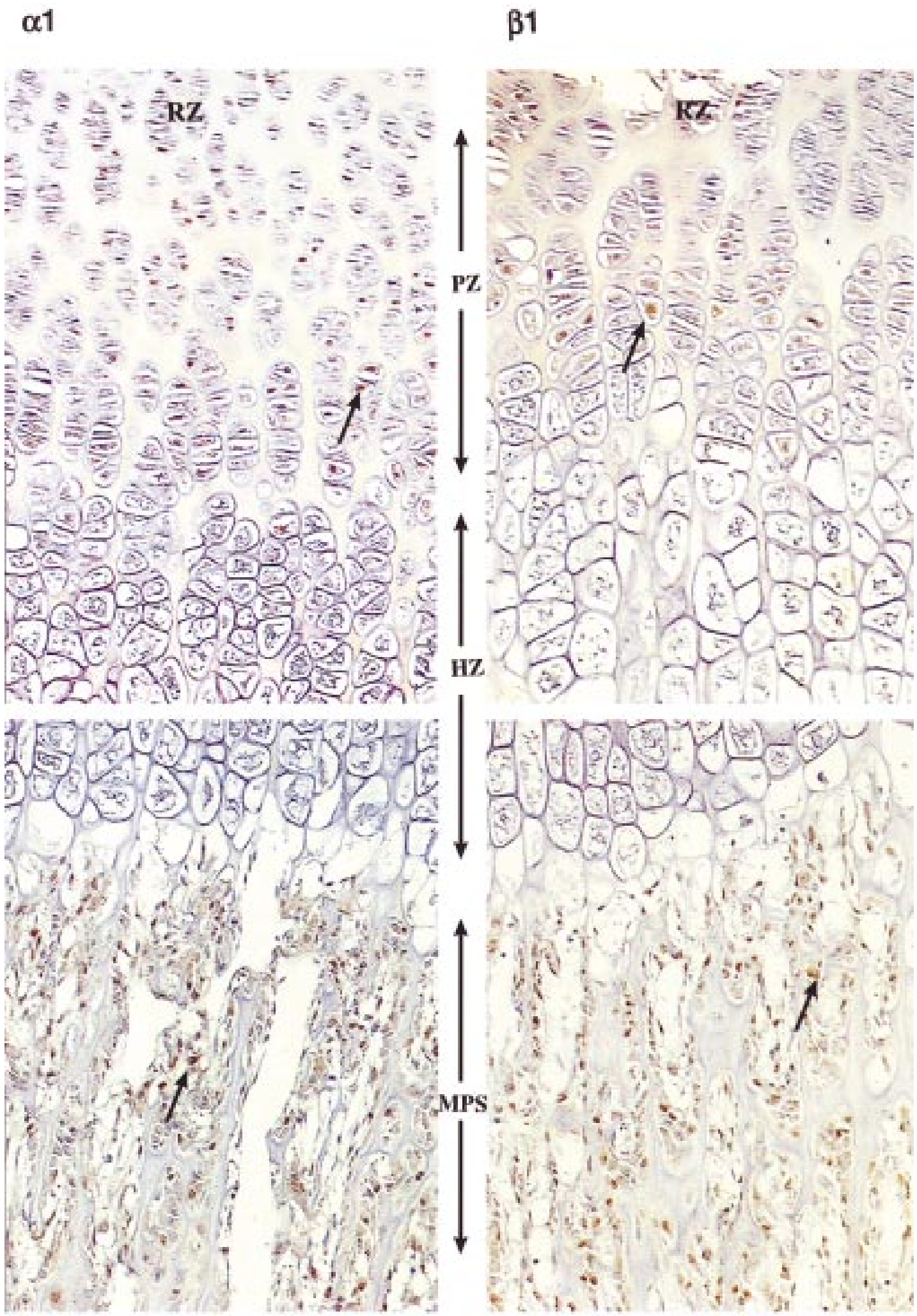


(Glantschnig et al. 1996) may be directly responsive to $T_{3}$, whereas IGF-I receptor mRNA is induced in rat chondrocytes after $96 \mathrm{~h}$ of $\mathrm{T}_{3}$ treatment (Ohlsson et al. 1992). Although the actions of GH and IGF-I are closely related, their direct effects on growth plate chondrocytes are likely to differ. Whilst GH receptors are expressed in the resting zone, IGF-I mRNA and protein are not, although IGF-I expression within the remainder of the rat growth plate may be regulated by GH (Ohlsson et al. 1993, Nilsson et al . 1994). The localisation of IGF-I receptors within discrete layers of the epiphyseal growth plate has not been reported, so IGF-I target cells cannot be identified with certainty, although it is likely that receptors are located predominantly in proliferating cells (Loveridge \& Farquharson 1993).

It is apparent that the interplay between GH, IGF-I and $\mathrm{T}_{3}$ at the growth plate is complex. It has been proposed that $\mathrm{GH}$ stimulates differentiation of resting zone chondrocyte precursor cells and that IGF-I stimulates their subsequent clonal expansion. The role of $\mathrm{T}_{3}$ is postulated to terminate clonal expansion and proliferation, and to induce terminal hypertrophic chondrocyte differentiation (Ohlsson et al. 1993).

\section{Oestrogen effects on growth and expression of its receptor in bone}

In humans, oestrogens are essential for the growth spurt at puberty and for epiphyseal growth plate fusion. The effects of oestrogen are not well defined, but are likely to be both indirect and direct, as oestrogens influence $\mathrm{GH}$ secretion in man (Nilsson et al. 1994), and human chondrocytes have been shown to express oestrogen receptors (ER) in intact bone (Braidman et al. 1995) and in vitro (Rosner et al. 1982, Dayani et al. 1988). In addition, expression of ER protein has been demonstrated in osteocytes, but not osteoblasts, within intact human, porcine and guinea pig bone slices, using immunohistochemical techniques (Braidman et al. 1995), whereas low levels of ER have been documented in primary cultures of human and murine osteoblasts (Pensler et al. 1990, Ikegami et al. 1993).

\section{Interactions between $T_{3}$ and oestrogen}

Early studies of cultured rat osteoblastic cells were suggestive of interactions between $T_{3}$ and oestrogens in bone
(Egrise et al. 1990). Recent studies have investigated interactions between oestrogen and $\mathrm{T}_{3}$ in vivo using the ER agonist, oestradiol, the partial agonist/antagonist, tamoxifen, and the pure antagonist, ICI 182780 , in the ovariectomized-thyroidectomized rat (DiPippo et al. 1995, DiPippo \& Powers 1997). These studies have suggested that the effects of oestrogen on the skeleton may result from a direct antagonism of the normal actions of $T_{3}$. In particular, tamoxifen appeared to act as a $\mathrm{T}_{3}$ antagonist in terms of its ability to increase tibial length. These interactions have been proposed to be mediated by crosstalk or competition between $\mathrm{T}_{3} \mathrm{R}$ and $\mathrm{ER}$ at the level of DNA binding in target gene promoters, as both receptors recognise identical consensus hormone response-element binding-site sequences. Some support for this at the molecular level has been obtained in vitro (Shao et al. 1995, Zhu et al. 1996, Klinge et al. 1997).

\section{Oestrogen resistance}

The effects of oestrogen on the skeleton are likely to be important in both sexes in humans, given the skeletal abnormalities (delayed epiphyseal closure, eunuchoid proportions, osteoporosis) seen both in a male patient with oestrogen resistance caused by a homozygous mutation of the ER (Smith et al. 1994) and in a second male with aromatase deficiency (Morishima et al. 1995). The clear-cut epiphyseal plate abnormality and bone loss seen in oestrogen resistance contrast with the complexities of the skeletal phenotype seen in RTH syndromes, as described earlier. In the single case of an ER mutation causing recessive hormone resistance (Smith et al. 1994), the homozygous defect resulted in complete absence of a functional ER protein, thereby contrasting with the heterozygous dominant-negative nature of RTH. For this reason, it is difficult to compare the skeletal phenotypes between the two conditions; however, it is intriguing to speculate that variability in the RTH phenotype may in part result from abnormal interactions between mutant $\mathrm{T}_{3} \mathrm{R} \beta$ and normal ER proteins.

\section{Androgen effects on growth and expression of its receptor in cartilage}

Androgens are also important for male linear growth and epiphyseal maturation and closure. Testosterone binding

Figure 2 Longitudinal sections (original magnification $\times 400$ ) of decalcified rat proximal tibiae, showing immunolocalisation of $T_{3} R \alpha 1$ (left panels) and $T_{3} R \beta 1$ (right panels) within distinct zones of the growth plate, using isoform-specific rabbit polyclonal antibodies against human $T_{3} R \alpha 1$ and $T_{3} R \beta 1$ proteins (Macchia et al. 1990, Falcone et al. 1992), which we have demonstrated to recognise rat $T_{3} R$ isoforms specifically in bone cells, using western blotting (Williams et al. 1994, Bland et al. 1997). The upper panels show reserve (RZ), proliferative (PZ) and proximal hypertrophic $(\mathrm{HZ})$ zones; the lower panels show the distal hypertrophic zone ( $\mathrm{HZ})$ and metaphyseal primary spongiosum (MPS). Nuclei staining positive for $T_{3} R \alpha 1$ or $T_{3} R \beta 1$ proteins were visualised using diaminobenzidine in sections counterstained with haematoxylin. Marked specific nuclear staining was seen in all cells of the RZ, whereas most PZ chondrocytes also stained positive for both $\mathrm{T}_{3}$ Rs. In contrast, chondrocytes throughout the HZ did not stain for either $\mathrm{T}_{3} \mathrm{R}$ isoform. In the MPS, nuclei of invading osteoblasts stained strongly positive for both $\mathrm{T}_{3} \mathrm{R} \alpha 1$ and $\beta 1$ proteins. Arrows indicate examples of positive-staining nuclei in PZ chondrocytes and MPS invading osteoblasts. 
sites have been described in epiphyseal chondrocytes from many species, including humans (Carrascosa et al. 1990), and differing responses to both oestrogen and testosterone between the sexes have been reported in vitro in humans, rabbits and rats (Corvol et al. 1987, Carrascosa et al. 1990, Somjen et al. 1991, Schwartz et al. 1994). 5a-Reductase activity has also been detected in rat and human epiphyseal chondrocytes (Ackerman \& Hamilton 1976, Blanchard et al. 1991), and aromatase activity is expressed in human cartilage (Blanchard et al. 1991). Androgens stimulate mineralisation of rat bone matrix implants in vitro (Kapur \& Reddi 1989), increase rat tibial growth plate width when injected directly (Ren et al. 1989), and may promote rat chondrocyte differentiation (Schwartz et al. 1994), although others have documented increased proliferative responses of rat chondrocytes to both testosterone and oestrogen in vivo and in vitro (Somjen et al. 1991).

\section{Interactions between sex steroids and GH/IGF-I signalling}

Both androgens and oestrogens have also been reported to interact with the IGF-I pathway in rabbit chondrocytes (Itagane et al. 1991), although others have shown that testosterone does not affect IGF-I expression in the liver or alter IGF and IGF-I receptor expression in the growth plate of rats (Phillip et al. 1992). Androgens and oestrogens differentially regulate $\mathrm{GH}$ receptor mRNA expression (induced by testosterone, inhibited by oestrogen) in rabbit liver and growth plates, and both hormones stimulate $\mathrm{GH}$ secretion (Yu et al. 1996). There are no reports, however, of interactions between androgens and $\mathrm{T}_{3}$ in skeletal cells or on the control of linear growth in any species.

\section{$1,25(\mathrm{OH})_{2}$-vitamin $\mathrm{D}_{3}$ effects on growth and expression of its receptor in cartilage}

Vitamin D deficiency in man produces abnormal expansion of the growth plate as a result of widening of the hypertrophic zone; these features are also seen in the epiphyses of VDR knockout mice (Yoshizawa et al. 1997). This could be due either to a delay in hypertrophic chondrocyte apoptosis or to acceleration of proliferating chondrocyte differentiation to hypertrophic cells; evidence from in vitro studies implicates the latter mechanism. Treatment of rabbit growth plate chondrocytes with $1,25(\mathrm{OH})_{2}$-vitamin $\mathrm{D}_{3}$ results in reduced alkaline phosphatase activity and a delay in differentiation to the hypertrophic phenotype (Kato et al. 1990). These effects are opposite to those induced by $\mathrm{T}_{3}$. Thus $1,25(\mathrm{OH})_{2}-$ vitamin $\mathrm{D}_{3}$ inhibits precocious chondrocyte hypertrophy and its deficiency destroys the balance of inhibition and stimulation of chondrocyte maturation, leading to widening of the hypertrophic zone in rachitic growth plates. Nuclear receptors for $1,25(\mathrm{OH})_{2}$-vitamin $\mathrm{D}_{3}$ have been demonstrated in murine, rat and rabbit chondrocytes in vitro (Jikko et al. 1993, Klaus et al. 1994, Balmain et al.
1995, Akiyama et al. 1996) and in sections of chicken and rat growth plates (Klaus et al. 1991, Berry et al. 1996). They are expressed throughout the growth plate region, but are most concentrated in proliferative and hypertrophic cells (Klaus et al. 1991, Berry et al. 1996). Studies on murine cells in vitro suggest that the recruitment of chondrocytes from progenitor stem cells and the progression of chondrocyte differentiation are both inhibited by $1,25(\mathrm{OH})_{2}$-vitamin $\mathrm{D}_{3}$ (Akiyama et al. 1996).

\section{Retinoid effects on growth and expression of their receptors in cartilage}

Retinoids exert profound effects on the developing skeleton and have important roles in limb bud development, anterior/posterior axis orientation, chondrogenesis, growth plate maturation and chondrocyte apoptosis. Retinoids are potent teratogens that cause intrauterine abnormalities of limb formation and promote epiphyseal plate closure in animal studies (Standeven et al. 1996). Expression of retinoid receptors has been widely documented in developing cartilage and their ontogeny has been implicated in control of endochondral bone formation during mouse embryogenesis (Noji et al. 1989, Dolle et al. 1990, Ruberte et al. 1990, Mendelsohn et al. 1991, Lohnes et al. 1993, Luo et al. 1995, Sucov et al. 1995). The major effects of retinoids on skeletal formation occur during chondrogenesis, and RAR $\alpha$ is required for initiation of chondrocyte differentiation (Cash et al. 1997). Northern blotting analysis of retinoid receptor expression in cultured rat chondrocytes has revealed expression of $\operatorname{RAR} \alpha$ and $\gamma$ and $\operatorname{RXR} \alpha$ and $\beta$ mRNAs, whereas RAR $\beta$ and RXR $\gamma$ transcripts are not expressed (Hagiwara et al. 1996). Retinoids regulate collagen gene transcription and suppress expression of the chondrocyte phenotype, in cultured rat and rabbit cells, that is characterised by collagen type II expression (Ballock et al. 1994, Benya \& Padilla 1986). All-trans retinoic acid inhibits cartilage matrix synthesis (Horton et al. 1987), and both all-trans retinoic acid and 9-cis retinoic acid decrease rat chondrocyte proliferation in culture (Hagiwara et al. 1996). Thus retinoids promote the differentiation of cultured chondrocytes to cells with a more osteoblast-like phenotype (Gentili et al. 1993).

\section{Interactions between $T_{3}$ and 1,25(OH) ${ }_{2}$-vitamin $\mathrm{D}_{3}$ and retinoids}

Whereas $\mathrm{T}_{3} \mathrm{R}, \mathrm{VDR}, \mathrm{RAR}$ and $\mathrm{RXR}$ proteins are each expressed in cartilage, there is no formal documentation to show which of the various receptor isoforms are co-expressed in individual chondrocytes, as has been shown in rat osteoblastic cells (Williams et al. 1994, Bland et al. 1997). Despite this, antagonistic interactions between 9-cis retinoic acid and $1,25(\mathrm{OH})_{2}$-vitamin $\mathrm{D}_{3}$ during chick limb bud chondrogenesis, which implicate RXR and VDR heterodimer formation, have been documented 


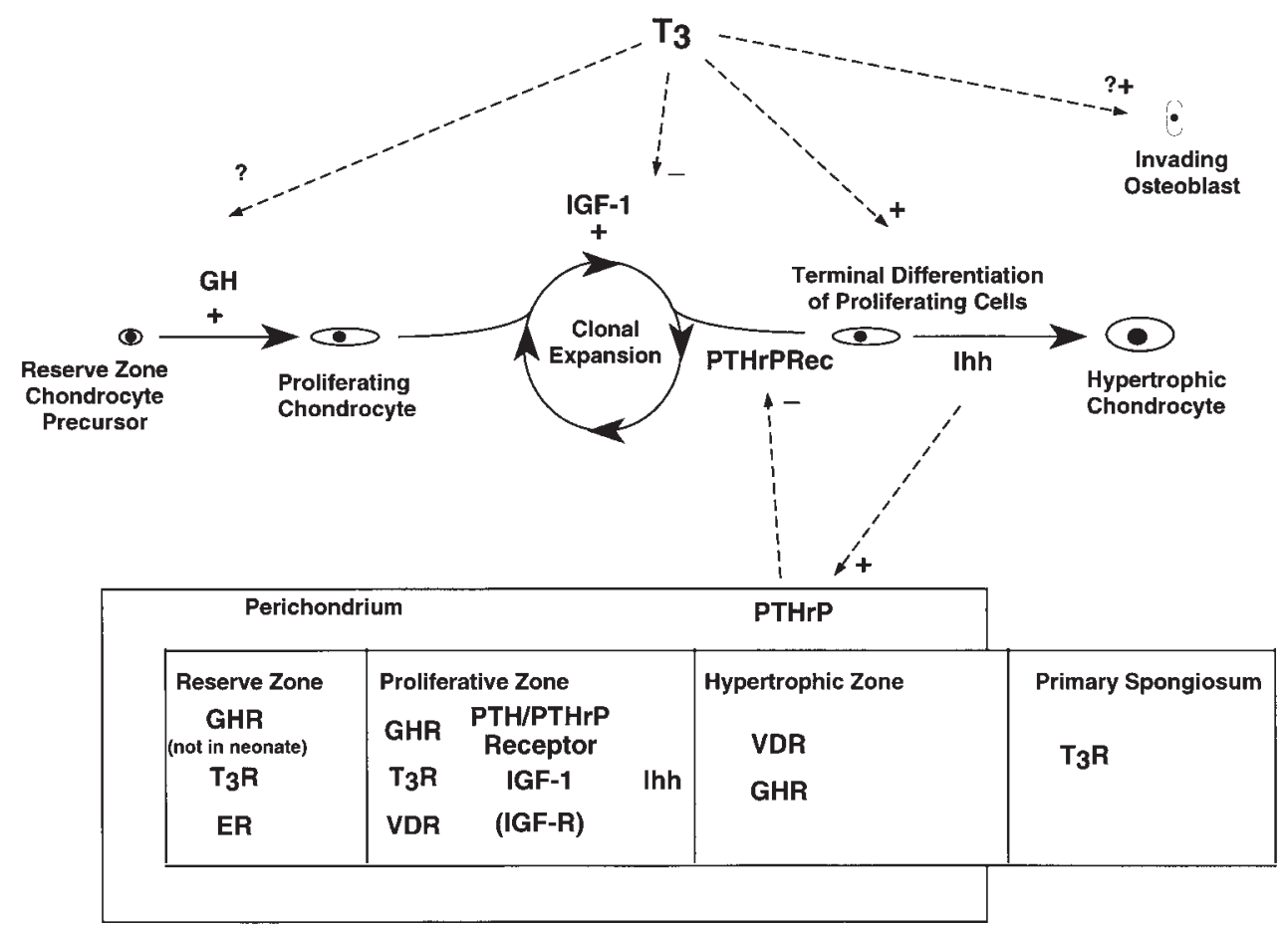

Figure 3 In the upper part of the figure, some of the signals that contribute to progression of a chondrocyte from the reserve zone through proliferation and on to hypertrophy are shown; a representation of the growth plate regions in which various hormone receptors and the Ihh/PTHrP feedback loop components are expressed is shown in the lower part. The known and proposed actions of $\mathrm{T}_{3}$ are shown at the top of the figure. Reserve zone chondrocytes differentiate to proliferating cells by a process that is stimulated by $\mathrm{GH}$ and may be affected by $\mathrm{T}_{3}$, as reserve cells express $\mathrm{T}_{3}$ Rs. Proliferating cells undergo clonal expansion, a process that is stimulated by IGF-1 and probably inhibited by $\mathrm{T}_{3}$, and begin to express the PTH/PTHrP receptor before commitment to hypertrophy. Terminal differentiation towards the hypertrophic phenotype is induced by $\mathrm{T}_{3}$ and committed cells synthesise and secrete lhh. Ihh acts on perichondrial cells to stimulate synthesis and release of PTHrP. PTHrP acts on uncommitted proliferating cells that express the PTH/PTHrP receptor to inhibit cell differentiation, thereby delaying cell maturation and reducing Ihh synthesis to complete a feedback control loop (Lanske et al. 1996, Vortkamp et al. 1996). In addition, $\mathrm{T}_{3}$ probably acts directly on primary spongiosum osteoblasts to facilitate their invasion from the bone marrow vasculature. The known extent of expression of growth hormone receptor (GHR) (Ohlsson et al. 1993, Werther et al. 1993), $T_{3}$ receptor $\alpha 1$ and $\beta 1$ ( $\left.T_{3} R\right)$ (Robson et al. 1997), vitamin D receptor (VDR) (Klaus et al. 1991, Berry et al. 1996), oestrogen receptor (ER) (Braidman et al. 1995), and IGF-1 (Loveridge \& Farquharson 1993, Ohlsson et al. 1993) proteins within the growth plate are shown for comparison with the region in which components of the feedback loop are expressed. The IGF-1 receptor (IGF-R) has been suggested to be expressed within the proliferative zone (Loveridge \& Farquharson 1993). A detailed analysis of the growth plate regions and individual chondrocytes that co-express various combinations of these molecules will facilitate development of a molecular understanding of the regulation of endochondral bone formation.

recently (Tsonis et al. 1996). Furthermore, a recent report suggested that $\mathrm{T}_{3}$-induced terminal differentiation of rat growth plate chondrocytes is inhibited by $1,25(\mathrm{OH})_{2^{-}}$ vitamin $\mathrm{D}_{3}$ and retinoids (Zhou et al. 1997), indicating that interactions between these hormones are likely to play a part in the mediation of $\mathrm{T}_{3}$ action in cartilage, as we have shown in osteoblastic cells (Williams et al. 1994, Williams et al. 1995, Bland et al. 1997).

\section{Ihh/PTHrP feedback loop}

Ihh is a member of a conserved family of secreted proteins that have key roles in embryonic patterning in many organisms. In Drosophila, the Hedgehog protein regulates embryonic segmentation and anterior/posterior polarity during development. In vertebrates, three Hedgehog family members have been identified and these include the Ihh protein, which is expressed at high levels in prehypertrophic chondrocytes. PTHrP is structurally homologous to $\mathrm{PTH}$, binds to a common $\mathrm{PTH} / \mathrm{PTHrP}$ surface receptor and is produced in numerous tissues, including the growth plate perichondrium, from where it is secreted to act on receptors expressed in growth plate chondrocytes. Recent studies using chicken and mouse tissues have convincingly demonstrated that Ihh and 
PTHrP target PTH/PTHrP receptor expressing growth plate chondrocytes in a negative feedback loop to regulate the co-ordinated progression of chondrocyte maturation and hypertrophy (Lanske et al. 1996, Vortkamp et al. 1996). The feedback loop is shown schematically in Fig. 3, where its relationship to other hormone signalling pathways that act on the growth plate is also shown.

Thus prehypertrophic chondrocytes that are committed to the hypertrophic phenotype express and secrete Ihh, which regulates the rate of hypertrophic differentiation. Ihh acts directly on cells within the adjacent perichondrium to stimulate production and release of PTHrP. PTHrP is secreted, and acts, via its receptor on prehypertrophic uncommitted proliferative cells, to maintain cells in a proliferative state and delay or inhibit the onset of hypertrophy (Lee et al. 1996). The level of Ihh expression by committed cells has been proposed to regulate the number of cells leaving the proliferative stage to enter hypertrophy. As cells progress to full hypertrophy, the level of expression of Ihh diminishes and the negative feedback loop is attenuated, thereby allowing terminal differentiation to be completed; the more Ihh is secreted, the fewer cells are committed to the hypertrophic state, and vice versa. Thus both $\mathrm{PTHrP}$ and Ihh signalling pathways converge on $\mathrm{PTH} / \mathrm{PTHrP}$ receptor expressing cells, and both signalling molecules act to maintain chondrocyte proliferation and delay hypertrophic differentiation (Lanske et al. 1996, Vortkamp et al. 1996, Wallis 1996).

\section{Possible relationship between $T_{3}$ and Ihh/PTHrP signalling}

These actions are opposite to those of $\mathrm{T}_{3}$, which facilitates the differentiation of growth plate chondrocytes and the recruitment of cells to the proliferating zone (Lewinson et al. 1989, Carrascosa et al. 1992, Quarto et al. 1992, Ballock \& Reddi 1994, Lewinson et al. 1994). At present, the relationship between $\mathrm{T}_{3}$ signalling and the activity of the Ihh/PTHrP feedback loop is not known, although $\mathrm{T}_{3} \mathrm{R}$ proteins appear to be expressed in regions of the growth plate that may overlap with areas in which Ihh and $\mathrm{PTH} / \mathrm{PTHrP}$ are expressed. It is possible, therefore, that $\mathrm{T}_{3}$ may induce terminal hypertrophic chondrocyte differentiation by inhibiting the expression or actions of Ihh or the PTH/PTHrP receptor, both of which must be considered as potential $\mathrm{T}_{3}$ target genes in the epiphyseal growth plate.

\section{Conclusions}

The physiological and clinical effects of thyroid hormones on linear growth are well established. Growth plate responses to thyroid hormones have been detailed in histological studies and the effects of $\mathrm{T}_{3}$ on chondrocyte differentiation have been documented by cell biological methods. Surprisingly, however, specific populations of $\mathrm{T}_{3}$ target cells in growth plates have not yet been definitively identified and the molecular mechanisms of $\mathrm{T}_{3}$ action in cartilage have not been studied. These issues present a major challenge, as the actions of $\mathrm{T}_{3}$ at the growth plate involve highly complex interactions with other, incompletely defined, hormone signalling pathways.

It will be important, therefore, to localise precisely the expression of $T_{3} R$ in epiphyseal chondrocytes in relation to target cells for other interacting hormones (Fig. 3) and to determine how $\mathrm{T}_{3} \mathrm{R}$ expression is regulated during growth plate development and by other hormones. Such studies will facilitate the development of strategies for identification of $\mathrm{T}_{3}$ target genes associated with chondrocyte differentiation, and should help to define the molecular basis for interactions between $\mathrm{T}_{3}$ and other endocrine pathways in cartilage. Ultimately, a detailed analysis of the mechanism of $\mathrm{T}_{3}$ action in growth plate chondrocytes will contribute significantly to our understanding of the factors that regulate endochondral ossification during long bone growth.

\section{References}

Abu EO, Bord S, Horner A, Chatterjee VKK \& Compston JE 1997 The expression of thyroid hormone receptors in human bone. Bone 21 137-142.

Ackerman RJ Jr \& Hamilton DW 1976 Testosterone metabolism in male rat epiphysis. Calcified Tissue Research 20 31-40.

Akiyama H, Hiraki Y, Shigeno C, Kohno H, Shukunami C, Tsuboyama T, Kasai R, Suzuki F, Konishi J \& Nakamura T 1996 $1 \alpha, 25-\mathrm{Dihydroxyvitamin} \mathrm{D}_{3}$ inhibits cell growth and chondrogenesis of a clonal mouse EC cell line, ATDC5. Journal of Bone and Mineral Research $1122-28$.

Alini M, Kofsky Y, Wu W, Pidoux I \& Poole AR 1996 In serum-free culture thyroid hormones can induce full expression of chondrocyte hypertrophy leading to matrix calcification. Journal of Bone and Mineral Research 11 105-113.

Allain TJ \& McGregor AM 1993 Thyroid hormones and bone. Journal of Endocrinology 139 9-18.

Allain TJ, Chambers TJ, Flanagan AM \& McGregor AM 1992 Tri-iodothyronine stimulates rat osteoclastic bone resorption by an indirect effect. Journal of Endocrinology 133 327-331.

Ballock RT \& Reddi AH 1994 Thyroxine is the serum factor that regulates morphogenesis of columnar cartilage from isolated chondrocytes in chemically defined medium. Journal of Cell Biology 126 1311-1318.

Ballock RT, Heydemann A, Wakefield LM, Flanders KC, Roberts AB \& Sporn MB 1994 Inhibition of the chondrocyte phenotype by retinoic acid involves upregulation of metalloprotease genes independent of TGF- $\beta$. Journal of Cellular Physiology 159 340-346.

Balmain N, von Eichel B, Toury R, Belquasmi F, Hauchecorne M, Klaus G, Mehls O \& Ritz E 1995 Calbindin-D28K and -D9K and $1,25(\mathrm{OH})_{2}$ vitamin $\mathrm{D}_{3}$ receptor immunolocalization and mineralization induction in long-term primary cultures of rat epiphyseal chondrocytes. Bone 17 37-45.

Benya PD \& Padilla SR 1986 Modulation of the rabbit chondrocyte phenotype by retinoic acid terminates type II collagen synthesis without inducing type I collagen: the modulated phenotype differs from that produced by subculture. Developmental Biology 118 296-305. 
Berry JL, Farquharson C, Whitehead CC \& Mawer EB 1996 Growth plate chondrocyte vitamin $\mathrm{D}$ receptor number and affinity are reduced in avian tibial dyschondroplastic lesions. Bone 19 197-203.

Blanchard O, Tsagris L, Rappaport R, Duval Beaupere G \& Corvol M 1991 Age-dependent responsiveness of rabbit and human cartilage cells to sex steroids in vitro. Journal of Steroid Biochemistry and Molecular Biology 40 711-716.

Bland R, Sammons RL, Sheppard MC \& Williams GR 1997 Thyroid hormone, vitamin $\mathrm{D}$ and retinoid receptor expression and signalling in primary cultures of rat osteoblastic and immortalised osteosarcoma cells. Journal of Endocrinology 154 63-64.

Boersma B \& Wit JM 1997 Catch-up growth. Endocrine Reviews 18 646-661.

Bohme K, Conscience Egli M, Tschan T, Winterhalter KH \& Bruckner P 1992 Induction of proliferation or hypertrophy of chondrocytes in serum-free culture: the role of insulin-like growth factor-I, insulin, or thyroxine. Journal of Cellular Biology 116 1035-1042.

Bohme K, Winterhalter KH \& Bruckner P 1995 Terminal differentiation of chondrocytes in culture is a spontaneous process and is arrested by transforming growth factor- $\beta 2$ and basic fibroblast growth factor in synergy. Experimental Cell Research 216 191-198.

Braidman IP, Davenport LK, Carter DH, Selby PL, Mawer EB \& Freemont AJ 1995 Preliminary in situ identification of estrogen target cells in bone. Journal of Bone and Mineral Research 10 74-80.

Britto JM, Fenton AJ, Holloway WR \& Nicholson GC 1994 Osteoblasts mediate thyroid hormone stimulation of osteoclastic bone resorption. Endocrinology 134 169-176.

Burch WM \& Lebovitz HE 1982a Triiodothyronine stimulates maturation of porcine growth-plate cartilage in vitro. Journal of Clinical Investigation 70 496-504.

Burch WM \& Lebovitz HE $1982 b$ Triiodothyronine stimulation of in vitro growth and maturation of embryonic chick cartilage. Endocrinology 111 462-468.

Burch WM \& McCarty KS Jr 1984 Hormonal stimulation of avian embryonic cartilage growth in vitro: histologic and ultrastructural features. In Vitro 20 329-338.

Burch WM \& Van Wyk JJ 1987 Triiodothyronine stimulates cartilage growth and maturation by different mechanisms. American Journal of Physiology 252 E176-E182.

Carrascosa A, Audi L, Ferrandez MA \& Ballabriga A 1990 Biological effects of androgens and identification of specific dihydrotestosterone-binding sites in cultured human fetal epiphyseal chondrocytes. Journal of Clinical Endocrinology and Metabolism $\mathbf{7 0}$ 134-140.

Carrascosa A, Ferrandez MA, Audi L \& Ballabriga A 1992 Effects of triiodothyronine $\left(\mathrm{T}_{3}\right)$ and identification of specific nuclear $\mathrm{T}_{3}$-binding sites in cultured human fetal epiphyseal chondrocytes. Journal of Clinical Endocrinology and Metabolism 75 140-144.

Cash DE, Bock CB, Schughart K, Linney E \& Underhill TM 1997 Retinoic acid receptor $\alpha$ function in vertebrate limb skeletogenesis: a modulator of chondrogenesis. Journal of Cell Biology 136 445-457.

Compston JE 1993 Thyroid hormone therapy and the skeleton. Clinical Endocrinology 39 519-520.

Corvol MT, Carrascosa A, Tsagris L, Blanchard O \& Rappaport R 1987 Evidence for a direct in vitro action of sex steroids on rabbit cartilage cells during skeletal growth: influence of age and sex. Endocrinology 120 1422-1429.

Dayani N, Corvol MT, Robel P, Eychenne B, Moncharmont B, Tsagris L \& Rappaport R 1988 Estrogen receptors in cultured rabbit articular chondrocytes: influence of age. Journal of Steroid Biochemistry and Molecular Biology 31 351-356.

Diamond T, Nery L \& Hales I 1991 A therapeutic dilemma: suppressive doses of thyroxine significantly reduce bone mineral measurements in both premenopausal and postmenopausal women with thyroid carcinoma. Journal of Clinical Endocrinology and Metabolism 72 1184-1188.
DiPippo VA \& Powers CA 1997 Tamoxifen and ICI 182,780 interactions with thyroid hormone in the ovariectomizedthyroidectomized rat. Journal of Pharmacology and Experimental Therapeutics 281 142-148.

DiPippo VA, Lindsay R \& Powers CA 1995 Estradiol and tamoxifen interactions with thyroid hormone in the ovariectomizedthyroidectomized rat. Endocrinology 136 1020-1033.

Dolle P, Ruberte E, Leroy P, Morriss Kay G \& Chambon P 1990 Retinoic acid receptors and cellular retinoid binding proteins. I: A systematic study of their differential pattern of transcription during mouse organogenesis. Development 110 1133-1151.

Duncan WE, Chang A, Solomon B \& Wartofsky L 1994 Influence of clinical characteristics and parameters associated with thyroid hormone therapy on the bone mineral density of women treated with thyroid hormone. Thyroid 4 183-190.

Egrise D, Martin D, Neve P, Verhas M \& Schoutens A 1990 Effects and interactions of $17 \beta$-estradiol, $\mathrm{T}_{3}$ and $1,25(\mathrm{OH})_{2} \mathrm{D}_{3}$ on cultured osteoblasts from mature rats. Bone and Mineral 11 273-283.

Falcone M, Miyamoto T, Fierro Renoy F, Macchia E \& DeGroot LJ 1992 Antipeptide polyclonal antibodies specifically recognize each human thyroid hormone receptor isoform. Endocrinology 131 2419-2429.

Fisher D \& Plok D 1995 Thyroid disease in the fetus, neonate and child. In Endocrinology, pp 78-798. Ed LJ DeGroot. Philadelphia, PA, USA: WB Saunders.

Forrest D, Erway LC, Ng L, Altschuler R \& Curran T 1996a Thyroid hormone receptor $\beta$ is essential for development of auditory function. Nature Genetics 13 354-357.

Forrest D, Hanebuth E, Smeyne RJ, Everds N, Stewart CL, Wehner JM \& Curran T 19966 Recessive resistance to thyroid hormone in mice lacking thyroid hormone receptor $\beta$ : evidence for tissue-specific modulation of receptor function. EMBO Journal 15 3006-3015.

Fraichard A, Chassande O, Plateroti M, Roux JP, Trouillas J, Dehay C, Legrand C, Gauthier K, Kedinger M, Malaval L, Rousset B \& Samarut J 1997 The $\mathrm{T}_{3} \mathrm{R} \alpha$ gene encoding a thyroid hormone receptor is essential for post-natal development and thyroid hormone production. EMBO Journal 16 4412-4420.

Franklyn J, Betteridge J, Holder R, Daykin J, Lilley J \& Sheppard M 1994 Bone mineral density in thyroxine treated females with or without a previous history of thyrotoxicosis. Clinical Endocrinology 41 425-432.

Gentili C, Bianco P, Neri M, Malpeli M, Campanile G, Castagnola P, Cancedda R \& Cancedda FD 1993 Cell proliferation, extracellular matrix mineralization, and ovotransferrin transient expression during in vitro differentiation of chick hypertrophic chondrocytes into osteoblast-like cells. Journal of Cellular Biology 122 703-712.

Gevers EF, Milne J, Robinson IC \& Loveridge N 1996 Single cell enzyme activity and proliferation in the growth plate: effects of growth hormone. Journal of Bone and Mineral Research 11 1103-1111.

Glantschnig H, Varga F \& Klaushofer K 1996 Thyroid hormone and retinoic acid induce the synthesis of insulin-like growth factorbinding protein-4 in mouse osteoblastic cells. Endocrinology 137 281-286.

Glass CK 1994 Differential recognition of target genes by nuclear receptor monomers, dimers, and heterodimers. Endocrine Reviews $\mathbf{1 5}$ 391-407.

Hagiwara H, Inoue A, Nakajo S, Nakaya K, Kojima S \& Hirose S 1996 Inhibition of proliferation of chondrocytes by specific receptors in response to retinoids. Biochemical and Biophysical Research Communications 222 220-224.

Horton WE, Yamada Y \& Hassell JR 1987 Retinoic acid rapidly reduces cartilage matrix synthesis by altering gene transcription in chondrocytes. Developmental Biology 123 508-516.

Hunziker EB, Wagner J \& Zapf J 1994 Differential effects of insulin-like growth factor I and growth hormone on developmental stages of rat growth plate chondrocytes in vivo. Journal of Clinical Investigation 93 1078-1086. 
Ikegami A, Inoue S, Hosoi T, Mizuno Y, Nakamura T, Ouchi Y \& Orimo H 1993 Immunohistochemical and northern blot analysis of estrogen receptor in osteoblastic cells. Journal of Bone and Mineral Research 8 1103-1110.

Itagane Y, Inada H, Fujita K \& Isshiki G 1991 Interactions between steroid hormones and insulin-like growth factor-I in rabbit chondrocytes. Endocrinology 128 1419-1424.

Jikko A, Aoba T, Murakami H, Takano Y, Iwamoto M \& Kato Y 1993 Characterization of the mineralization process in cultures of rabbit growth plate chondrocytes. Developmental Biology 156 372-380.

Kapur SP \& Reddi AH 1989 Influence of testosterone and dihydrotestosterone on bone-matrix induced endochondral bone formation. Calcified Tissue International 44 108-113.

Kasono K, Sato K, Han DC, Fujii Y, Tsushima T \& Shizume K 1988 Stimulation of alkaline phosphatase activity by thyroid hormone in mouse osteoblast-like cells (MC3T3-E1): a possible mechanism of hyperalkaline phosphatasia in hyperthyroidism. Bone and Mineral 4 355-363.

Kato Y, Shimazu A, Iwamoto M, Nakashima K, Koike T, Suzuki F, Nishii Y \& Sato K 1990 Role of 1,25-dihydroxycholecalciferol in growth-plate cartilage: inhibition of terminal differentiation of chondrocytes in vitro and in vivo. Proceedings of the National Acadamy of Sciences of the USA 87 6522-6526.

Klaus G, Merke J, Eing H, Hugel U, Milde P, Reichel H, Ritz E \& Mehls O $19911,25(\mathrm{OH})_{2} \mathrm{D}_{3}$ receptor regulation and $1,25(\mathrm{OH})_{2} \mathrm{D}_{3}$ effects in primary cultures of growth cartilage cells of the rat. Calcified Tissue International 49 340-348.

Klaus G, von Eichel B, May T, Hugel U, Mayer H, Ritz E \& Mehls O 1994 Synergistic effects of parathyroid hormone and 1,25-dihydroxyvitamin $D_{3}$ on proliferation and vitamin $D$ receptor expression of rat growth cartilage cells. Endocrinology 135 1307-1315.

Klaushofer K, Varga F, Glantschnig H, Fratzl Zelman N, Czerwenka E, Leis HJ, Koller K \& Peterlik M 1995 The regulatory role of thyroid hormones in bone cell growth and differentiation. Journal of Nutrition 125 1996S-2003S.

Klinge CM, Bodenner DL, Desai D, Niles RM \& Traish AM 1997 Binding of type II nuclear receptors and estrogen receptor to full and half-site estrogen response elements in vitro. Nucleic Acids Research 25 1903-1912.

Krieger NS, Stappenbeck TS \& Stern PH 1988 Characterization of specific thyroid hormone receptors in bone. Journal of Bone and Mineral Research 3 473-478.

Lanske B, Karaplis AC, Lee K, Luz A, Vortkamp A, Pirro A, Karperien M, Defize LHK, Ho C, Mulligan RC, Abou Samra AB, Juppner H, Segre GV \& Kronenberg HM 1996 PTH/PTHrP receptor in early development and Indian hedgehog-regulated bone growth. Science 273 663-666.

LeBron BA, Pekary AE, Mirell C, Hahn TJ \& Hershman JM 1989 Thyroid hormone $5^{\prime}$-deiodinase activity, nuclear binding, and effects on mitogenesis in UMR-106 osteoblastic osteosarcoma cells. Journal of Bone and Mineral Research 4 173-178.

Lee K, Lanske B, Karaplis AC, Deeds JD, Kohno H, Nissenson RA, Kronenberg HM \& Segre GV 1996 Parathyroid hormone-related peptide delays terminal differentiation of chondrocytes during endochondral bone development. Endocrinology 137 5109-5118.

Lewinson D, Harel Z, Shenzer P, Silbermann M \& Hochberg Z 1989 Effect of thyroid hormone and growth hormone on recovery from hypothyroidism of epiphyseal growth plate cartilage and its adjacent bone. Endocrinology 124 937-945.

Lewinson D, Bialik GM \& Hochberg Z 1994 Differential effects of hypothyroidism on the cartilage and the osteogenic process in the mandibular condyle: recovery by growth hormone and thyroxine. Endocrinology 135 1504-1510.

Lohnes D, Kastner P, Dierich A, Mark M, LeMeur M \& Chambon P 1993 Function of retinoic acid receptor $\gamma$ in the mouse. Cell $\mathbf{7 3}$ 643-658.
Loveridge N \& Farquharson C 1993 Studies on growth plate chondrocytes in situ: cell proliferation and differentiation. Acta Paediatrica, Supplement 391 42-48.

Luo J, Pasceri P, Conlon R A, Rossant J \& Giguere V 1995 Mice lacking all isoforms of retinoic acid receptor $\beta$ develop normally and are susceptible to the teratogenic effects of retinoic acid. Mechanisms in Development 53 61-71.

Macchia E, Nakai A, Janiga A, Sakurai A, Fisfalen ME, Gardner P, Soltani K \& DeGroot LJ 1990 Characterization of site-specific polyclonal antibodies to c-erbA peptides recognizing human thyroid hormone receptors $\alpha 1, \alpha 2$, and $\beta$ and native $3,5,3^{\prime}$-triiodothyronine receptor, and study of tissue distribution of the antigen. Endocrinology 126 3232-3239.

Mendelsohn C, Ruberte E, LeMeur M, Morriss Kay G \& Chambon P 1991 Developmental analysis of the retinoic acid-inducible RAR- $\beta$ 2 promoter in transgenic animals. Development 113 723-734.

Miell JP, Taylor AM, Zini M, Maheshwari HG, Ross RJ \& Valcavi R 1993 Effects of hypothyroidism and hyperthyroidism on insulin-like growth factors (IGFs) and growth hormone- and IGF-binding proteins. Journal of Clinical Endocrinology and Metabolism 76 950-955.

Morishima A, Grumbach MM, Simpson ER, Fisher C \& Qin K 1995 Aromatase deficiency in male and female siblings caused by a novel mutation and the physiological role of estrogens. Journal of Clinical Endocrinology and Metabolism 80 3689-3698.

Mosekilde L, Eriksen E \& Charles P 1990 Effects of thyroid hormone on bone and mineral metabolism. Endocrinology and Metabolism Clinics of North America 19 35-62.

Mundy GR, Shapiro JL, Bandelin JG, Canalis EM \& Raisz LG 1976 Direct stimulation of bone resorption by thyroid hormones. Journal of Clinical Investigation 58 529-534.

Nilsson A, Ohlsson C, Isaksson OG, Lindahl A \& Isgaard J 1994 Hormonal regulation of longitudinal bone growth. European Journal of Clinical Nutrition 48 S150-S160.

Noji S, Yamaai T, Koyama E, Nohno T \& Taniguchi S 1989 Spatial and temporal expression pattern of retinoic acid receptor genes during mouse bone development. FEBS Letters 257 93-96.

Ohlsson C, Nilsson A, Isaksson O, Bentham J \& Lindahl A 1992 Effects of tri-iodothyronine and insulin-like growth factor-I (IGF-I) on alkaline phosphatase activity, $\left[{ }^{3} \mathrm{H}\right]$ thymidine incorporation and IGF-I receptor mRNA in cultured rat epiphyseal chondrocytes. Journal of Endocrinology 135 115-123.

Ohlsson C, Isgaard J, Tornell J, Nilsson A, Isaksson OG \& Lindahl A 1993 Endocrine regulation of longitudinal bone growth. Acta Paediatrica, Supplement 391 33-40.

Pensler JM, Langman CB, Radesovich JA, Maminta JA, Mangkornkanok M, Higbee R \& Molteni A 1990 Sex steroid hormone receptors in normal and dysplastic bone disorders in children. Journal of Bone and Mineral Research 5 493-498.

Phillip M, Palese T, Hernandez ER, Roberts CT Jr, LeRoith D \& Kowarski AA 1992 Effect of testosterone on insulin-like growth factor-I (IGF-I) and IGF-I receptor gene expression in the hypophysectomized rat. Endocrinology 130 2865-2870.

Quarto R, Campanile G, Cancedda R \& Dozin B 1992 Thyroid hormone, insulin, and glucocorticoids are sufficient to support chondrocyte differentiation to hypertrophy: a serum-free analysis. Journal of Cell Biology 119 989-995.

Refetoff S, DeWind LT \& DeGroot LJ 1967 Familial syndrome combining deafmutism, stippled epiphyses, goiter, and abnormally high PBI: possible target organ refractoriness to thyroid hormone. Journal of Clinical Endocrinology and Metabolism 27 279-294.

Refetoff S, Weiss RE \& Usala SJ 1993 The syndromes of resistance to thyroid hormone. Endocrine Reviews 14 348-399.

Ren SG, Malozowski S, Sanchez P, Sweet DE, Loriaux DL \& Cassorla F 1989 Direct administration of testosterone increases rat tibial epiphyseal growth plate width. Acta Endocrinologica Copenhagen 121 401-405. 
Rizzoli R, Poser J \& Burgi U 1986 Nuclear thyroid hormone receptors in cultured bone cells. Metabolism 35 71-74.

Robson H, Hasserjian RP, Anderson E, Shalet SM \& Williams GR 1997 Localisation of thyroid hormone receptor $\left(T_{3} R\right)$ isoforms $\alpha 1$ and $\beta 1$ in rat tibial growth plate cartilage and adjacent bone. Journal of Endocrinology 155 (Suppl 2) O26.

Rosen ED, Beninghof EG \& Koenig RJ 1993 Dimerization interfaces of thyroid hormone, retinoic acid, vitamin $\mathrm{D}$, and retinoid $\mathrm{X}$ receptors. Journal of Biological Chemistry 268 11534-11541.

Rosner IA, Manni A, Malemud CJ, Boja B \& Moskowitz RW 1982 Estradiol receptors in articular chondrocytes. Biochemical and Biophysical Research Communications 106 1378-1382.

Ruberte E, Dolle P, Krust A, Zelent A, Morriss Kay G \& Chambon P 1990 Specific spatial and temporal distribution of retinoic acid receptor $\gamma$ transcripts during mouse embryogenesis. Development 108 213-222.

Sato K, Han DC, Fujii Y, Tsushima T \& Shizume K 1987 Thyroid hormone stimulates alkaline phosphatase activity in cultured rat osteoblastic cells (ROS 17/28) through 3,5,3'-triiodo-L-thyronine nuclear receptors. Endocrinology 120 1873-1881.

Schmid C, Schlapfer I, Futo E, Waldvogel M, Schwander J, Zapf J \& Froesch ER 1992 Triiodothyronine $\left(\mathrm{T}_{3}\right)$ stimulates insulin-like growth factor (IGF)-1 and IGF binding protein (IGFBP)-2 production by rat osteoblasts in vitro. Acta Endocrinologica Copenhagen 126 467-473.

Schneider DL, Barrett Connor EL \& Morton DJ 1994 Thyroid hormone use and bone mineral density in elderly women. Effects of estrogen. Journal of the American Medical Association 271 $1245-1249$.

Schrader M, Muller KM \& Carlberg C 1994 Specificity and flexibility of vitamin D signaling. Modulation of the activation of natural vitamin D response elements by thyroid hormone. Journal of Biological Chemistry 269 5501-5504.

Schwartz Z, Nasatzky E, Ornoy A, Brooks BP, Soskolne WA \& Boyan BD 1994 Gender-specific, maturation-dependent effects of testosterone on chondrocytes in culture. Endocrinology $\mathbf{1 3 4}$ 1640-1647.

Shao ZM, Sheikh MS, Rishi AK, Dawson MI, Li XS, Wilber JF, Feng P \& Fontana JA 1995 Thyroid hormone enhancement of estradiol stimulation of breast carcinoma proliferation. Experimental Cell Research 218 1-8.

Siddiqi A, Burrin JM, Hughes FJ, Monson JP \& Wood DF $1996 T_{3}$ increases IL-6 and IL-8 transcription through functional $\mathrm{T}_{3}$ receptors in human osteoblast-like cells. Journal of Bone and Mineral Research 11 (Suppl 1) S321.

Smith EP, Boyd J, Frank GR, Takahashi H, Cohen RM, Specker B, Williams TC, Lubahn DB \& Korach KS 1994 Estrogen resistance caused by a mutation in the estrogen-receptor gene in a man. New England Journal of Medicine 331 1056-1061.

Somjen D, Weisman Y, Mor Z, Harell A \& Kaye AM 1991 Regulation of proliferation of rat cartilage and bone by sex steroid hormones. Journal of Steroid Biochemistry and Molecular Biology $\mathbf{4 0}$ $717-723$.

Spagnoli A \& Rosenfeld RG 1996 The mechanisms by which growth hormone brings about growth. The relative contributions of growth hormone and insulin-like growth factors. Endocrinology and Metabolism Clinics of North America 25 615-631.

Standeven AM, Davies PJ, Chandraratna RA, Mader DR, Johnson AT \& Thomazy VA 1996 Retinoid-induced epiphyseal plate closure in guinea pigs. Fundamentals of Applied Toxicology 34 91-98.
Sucov HM, Izpisua Belmonte JC, Ganan Y \& Evans RM 1995 Mouse embryos lacking RXR $\alpha$ are resistant to retinoic-acid-induced limb defects. Development 121 3997-4003.

Tsonis PA, Sargent MT, Del Rio Tsonis K, \& Jung JC 1996 9-cis retinoic acid antagonizes the stimulatory effect of 1,25 dihydroxyvitamin $\mathrm{D}_{3}$ on chondrogenesis of chick limb bud mesenchymal cells: interactions of their receptors. International Journal of Developmental Biology 40 1053-1059.

Underwood LE \& Van Wyk JJ 1992 Normal and aberrant growth. In Williams Textbook of Endocrinology, pp 1079-1138. Eds JD Wilson \& DW Foster. Philadelphia, PA, USA: WB Saunders Company.

Van Auken M, Kang M-I, Quail J \& Baran DT 1997 T $_{3}$ increases IGF-I transcription in osteoblast cell cultures derived from adult vertebral bone marrow but not femoral bone marrow. Journal of Bone and Mineral Research 12 (Suppl 1) T414.

Vortkamp A, Lee K, Lanske B, Segre GV, Kronenberg HM \& Tabin CJ 1996 Regulation of rate of cartilage differentiation by Indian hedgehog and PTH-related protein. Science 273 613-622.

Wallis GA 1996 Bone growth: coordinating chondrocyte differentiation. Current Biology 6 1577-1580.

Weiss RE \& Refetoff S 1996 Effect of thyroid hormone on growth: lessons from the syndrome of resistance to thyroid hormone. Endocrinology and Metabolism Clinics of North America 25 719-730.

Werther GA, Haynes K, Edmonson S, Oakes S, Buchanan CJ, Herington AC \& Waters MJ 1993 Identification of growth hormone receptors on human growth plate chondrocytes. Acta Paediatrica, Supplement 391 50-53.

Williams GR, Bland R \& Sheppard MC 1994 Characterization of thyroid hormone $\left(T_{3}\right)$ receptors in three osteosarcoma cell lines of distinct osteoblast phenotype: interactions among $T_{3}$, vitamin $D_{3}$, and retinoid signaling. Endocrinology 135 2375-2385.

Williams GR, Bland R \& Sheppard MC 1995 Retinoids modify regulation of endogenous gene expression by vitamin $D_{3}$ and thyroid hormone in three osteosarcoma cell lines. Endocrinology 136 4304-4314.

Wolf M, Ingbar SH \& Moses AC 1989 Thyroid hormone and growth hormone interact to regulate insulin-like growth factor-I messenger ribonucleic acid and circulating levels in the rat. Endocrinology 125 2905-2914.

Yoshizawa T, Handa Y, Uematsu Y, Takeda S, Sekine K, Yoshihara Y, Kawakami T, Arioka K, Sato H, Uchiyama Y, Masushige S, Fukamizu A, Matsumoto T \& Kato S 1997 Mice lacking the vitamin $\mathrm{D}$ receptor exhibit impaired bone formation, uterine hypoplasia and growth retardation after weaning. Nature Genetics 16 391-396.

Yu YM, Domene HM, Sztein J, Counts DR \& Cassorla F 1996 Developmental changes and differential regulation by testosterone and estradiol of growth hormone receptor expression in the rabbit. European Journal of Endocrinology 135 583-590.

Zhou X, Mita BC \& Ballock RT 1997 Both vitamin D and retinoic acid inhibit thyroid hormone induced terminal differentiation of growth plate chondrocytes. Journal of Bone and Mineral Research 12 (Suppl 1) F270.

Zhu YS, Yen PM, Chin WW \& Pfaff DW 1996 Estrogen and thyroid hormone interaction on regulation of gene expression. Proceedings of the National Academy of Sciences of the USA 93 12587-12592.

\section{Received 11 November 1997}

Accepted 2 February 1998 